\title{
Kiképzés és szimuláció \\ A MARCUS konstruktív szimulációs rendszer továbbfejlesztési lehetőségei
}

DOI 10.17047/Hadtud.2021.31.E.248

Az utóbbi évtizedben a korszerü kiképzésben, a világ minden haderejénél meghatározóvá vált a szimulációs eszközök alkalmazása. A Zrínyi Honvédelmi és Haderőfejlesztési Program (Zrínyi HHP) keretében beszerzésre kerülö új eszközök megjelenésével szükség van a Magyar Honvédségnél rendelkezésre álló szimulációs képességek hadműveleti/harcászati követelményeinek felülvizsgálatára.

A konstruktív és virtuális szimulációs kiképzés területén, Magyarország jelentős nemzeti képességekkel rendelkezik. Az új feladatok egyben új lehetőségek is a hazai védelmi ipar számára. Jelen tanulmány az alkalmazók által megfogalmazott igényeket, valamint a magyar fejlesztésü MARCUS konstruktív szimulációs rendszerrel kapcsolatos fejlesztői terveket foglalja össze.

KULCSSZAVAK: ARCUS, EUROSIM, konstruktív szimuláció (CAX), virtuális szimuláció, NATO interoperabilitás, Katonai-, rendvédelmi-, katasztrófavédelmi szimulátorok, KRONOS, Zrínyi Honvédelmi és Haderőfejlesztési Program

\section{Training and Simulation. Some Further Development Opportunities of the MARCUS Constructive Simulation System}

In the last decade, the use of simulation tools has become dominant in modern training for all defence forces in the world. With the appearance of new equipment to be procured within the framework of the Zrinyi National Defense and Force Development Program, it is necessary to review the operational / tactical requirements of the simulation capabilities available at the Hungarian Defence Forces.

In the field of constructive and virtual simulation training solutions, Hungary has significant national capabilities. The new tasks are also new opportunities for the domestic defense industry. The present study summarizes the requirements expressed by users, as well as the development plans about the hungarian MARCUS constructive simulation system.

KEYWORLDS: MARCUS, EUROSIM, Constructive simulation (CAX), virtual simulation, NATO interoperability, Military-, law enforcement-, disaster management simulators, KRONOS, Zrinyi National Defense and Force Development Program

\footnotetext{
${ }^{1}$ Nemzeti Közszolgálati Egyetem, Hadtudományi és Honvédtisztképző Kar, Katonai Műszaki Doktori Iskola, doktorandusz - National University of Public Service, Faculty of Military Sciences and Officer Training Doctoral School of Military Engineering, PhD Student; e-mail: zsitnyanyi@gammatech.hu; https://doi.org/0000-0003-3571-652X.

A szerző köszönetet mond Horváth Lászlónak, az ARTIFEX Szimulációs és Kiképzési Rendszerek Kft. ügyvezetőjének a cikk megírásához nyújtott segítségéért.
} 


\section{Bevezetés}

Magyarország a konstruktív és virtuális szimulációs kiképzés területén igen jelentős nemzeti képességekkel rendelkezik. A Magyar Honvédség (MH) várpalotai Szimulációs Központjában a nemzetközileg is jelentős MARCUS ${ }^{2}$ konstruktív szimuláció üzemel, amely biztosítja a törzskiképzés teljes körü kiszolgálását. Az elmúlt 30 évben több mint 20 hazai fejlesztés szolgálta a kiképzés támogatását, költséghatékony megoldások születtek, a fejlesztés, üzemeltetés és karbantartás még takarékosabb és rugalmasabb lett.

A nemzetközi trendek egyértelműen a szimulációs kiképzés további térnyerését vetítik elöre, ennek anyagi és szakmai okai is vannak. ${ }^{3}$ Feltételezem, hogy a Magyarországon folyamatban lévő beszerzések miatt további szimulációs rendszerek vásárlása, beüzemelése és integrációja valósul meg, amelyek hosszú távú költséghatékony fenntartása és továbbfejlesztése hazai bázison, a piaci szereplők együttmüködésével is megoldható.

Jelen tanulmány a jelenlegi és a lehetséges alkalmazók által megfogalmazott igényeket, valamint a magyar fejlesztésű MARCUS konstruktív szimulációs rendszerrel kapcsolatos jelenlegi munkálatokat és fejlesztői terveket foglalja össze. A témakör jelentőségét az adja, hogy a várpalotai Szimulációs Központ lehet az alapja a $\mathrm{PESCO}^{4}$ keretében fejlesztendő európai kiképzési és szimulációs központnak (EUROSIM). ${ }^{5}$

\section{Szimulátorok alkalmazása a katonai kiképzések során}

A szimulátorokat 3 fő csoportba sorolhatjuk: élő, virtuális és konstruktív. A MH mindhárom szimulátortípust használja kiképzésre. Az élő (live) szimulátorok a valós eszközökkel és terepen végrehajtott gyakorlatokat támogatják, például MILES. ${ }^{6}$ A virtuális (virtual) szimulátorok az egyéni vagy kis alegység kiképzés eszközei. A trenazsőr vezetői, kötelék taktikai szimulátoroknak igen széles választéka található meg a nemzetközi kiképzési rendszerben. A Magyar Honvédségnél ilyen eszközök a Gripen pilóta szimulátor, a nemzetközi kiképzési feladatokat is ellátó $\mathrm{JTAC}^{7}$ az elmúlt időszakban telepített Thales által gyártott helikopterszemélyzet- szimulátor, vagy a sok éve, több helyszínen üzemelő $\mathrm{KRONOS}^{8}$ szakasz szintű szimulátor. A konstruktív (constructive) szimulációs rendszereket törzskiképzésre, jellemzően század szinttől felfelé, valamint a katonai oktatás céljaira használnak. Ezekből a rendszerekből bonyolultságuk miatt lényegesen szükebb a paletta a

\footnotetext{
${ }^{2}$ MARCUS: Konstruktív CAX szimuláció.

${ }^{3}$ Military Training and Simulation. The Concise Global Industry Guide, October 2021. Shephard Handbook Issue 17. https://www.shephardmedia.com/news/training-simulation/read-the-latest-military-training-andsimulation-h/ (Letöltés ideje: 2021. 12. 11.)

${ }^{4}$ Permanent Structured Cooperation -állandó strukturált együttmüködés, az Európai Unió közös biztonság- és védelempolitikájának része.

5 PESCO Projects. Integrated European Joint Training and Simulation Centre (EUROSIM). Koordinátor Magyarország. https://pesco.europa.eu/project/integrated-european-joint-training-and-simulation-centre-eurosim/ (Letöltés ideje: 2021. 12. 11.)

${ }^{6}$ MILES: Multiple Integrated Laser Engagement System / Többszörösen integrált lézeres harci szimulátor rendszer.

${ }^{7}$ JTAC: Joint Terminal Attack Controller Simulator / Elöretolt Repülésirányító Kiképző Rendszer.

${ }^{8}$ KRONOS: Szakaszszintủ rekonfigurálható virtuális szimulátor.
} 
nemzetközi piacon, Magyarországon a MARCUS szimulációs rendszer lett rendszeresítve. A központ Várpalotán, a MH Bakony Harckiképzö Központ (BHK) Szimulációs Gyakorló Központjában lett kialakítva, ezzel párhuzamosan a kisebb kiépítésủ szimulációs rendszerek (MARS ${ }^{9}$ /MARCUS zászlóalj) az MH számos helyőrségében és a Nemzeti Közszolgálati Egyetemen (NKE) működnek. Ezek a rendszerek képesek külön-külön, valamint összekapcsolva is müködni.

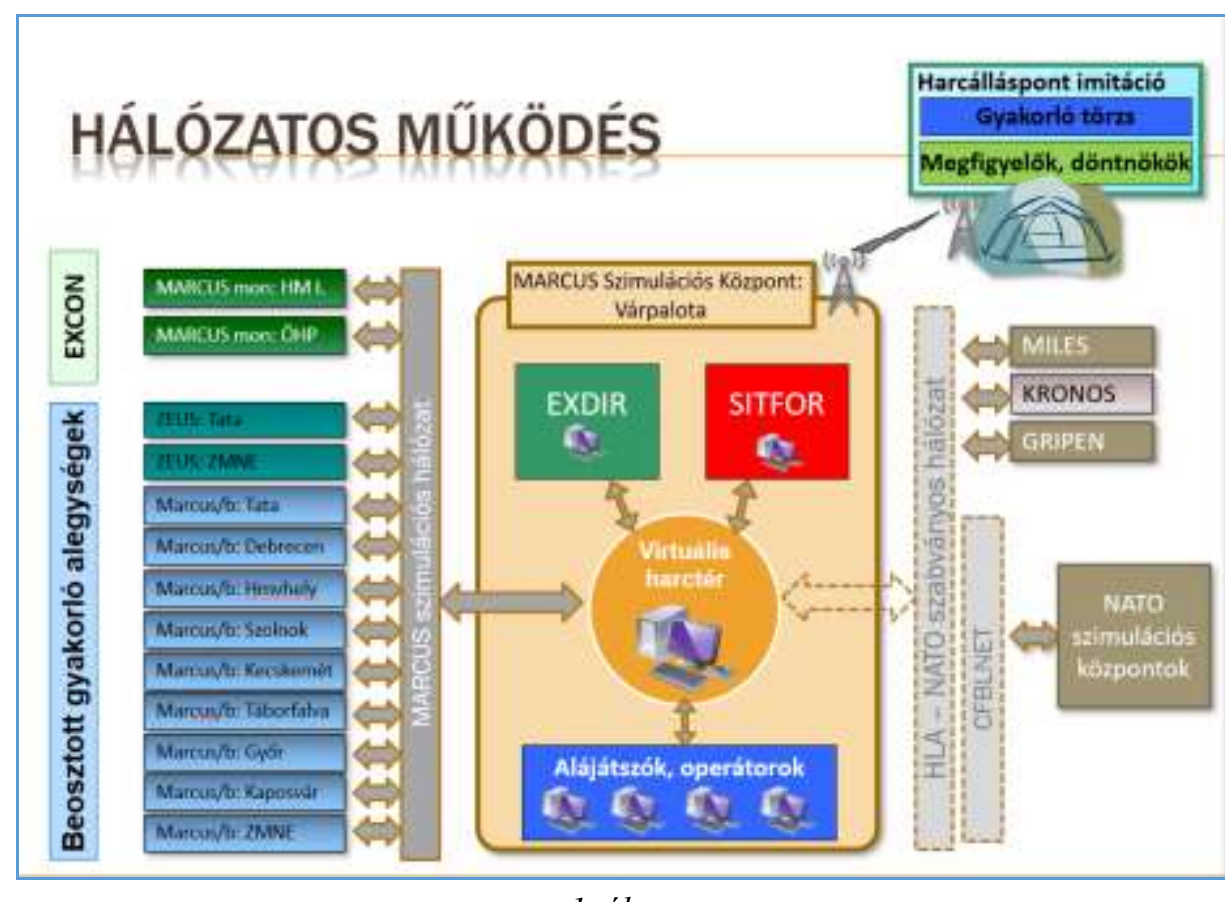

1. ábra.

MARCUS szimuláció a BHK-ban

(Forrás: ARTIFEX Kft., MARCUS_2020.pptx)

A MARCUS rendszer szabványos HLA $^{10}$ Evolved felületen keresztül összeköthető hazai (például KRONOS) és más nemzetek egyéb szimulációs rendszereivel (például JCATS). Szintén megvalósítható a MARCUS-C2 ${ }^{11}$ kapcsolat. A MARCUS szimulátor egy összhaderőnemi integrált rendszer, amely nem csak a katonai müveletek, hanem a katasztrófavédelem, terrorizmus, békefenntartás és egyéb területek modellezésére is alkalmas. A szimulációs rendszer a 2000. évi bevezetése óta folyamatosan igazodik a megváltozott geopolitikai helyzethez, doktrínákhoz a legfrissebb verziókban bővülnek és továbbfejlesztésre kerülnek az alkalmazási területek. Jelenleg a MARCUS v 14 a legfrissebb elérhető verzió és a v20-as változat készül.

\footnotetext{
${ }^{9}$ MARS (Marcus/b): Zászlóaljszintű konstruktív szimulátor.

${ }^{10}$ HLA Evolved: IEEE 1516-2010 - IEEE Standard for Modeling and Simulation (M\&S) High Level Architecture (HLA) - Framework and Rules, NATO STANAG 5603 / IEEE (a világ egyik legnagyobb, eredetileg villamosmérnököket egyesítő nemzetközi szervezete) Modellezés és szimuláció szabvány: Felsö szintü architektúra - Keretrendszer és szabályok.

${ }^{11} \mathrm{C} 2$ : Command and Control / Vezetés és irányítás.
} 


\section{A konstruktív szimulációs gyakorlatok $\left(C A X^{12}\right)$ megnövekedett jelentösége}

Az utóbbi évtizedben, elsősorban az erőforráshiány miatt (technika, humán, pénz, idő, hely) a korszerü kiképzésben, a világ minden hadseregében meghatározóvá vált a szimulációs eszközök alkalmazása. Segítségükkel kockázatmentes környezetben, költséghatékonyan, környezetvédelmi szempontokat is figyelembe véve, a valóságot megközelítő körülmények között lehet végrehajtani a hadgyakorlatokat, kiképzéseket. ${ }^{13}$ Megjelent az igény az e-learning képességek kiépítésére is, az új módszertan illeszkedik a szövetségesi rendszerben alkalmazott új struktúrákhoz is.

A Zrínyi Honvédelmi és Haderőfejlesztési Program (HHP) keretében beszerzésre kerülő új eszközök megjelenésével szükség van a Magyar Honvédségnél rendelkezésre álló szimulációs képességek hadműveleti/harcászati követelményeinek felülvizsgálatára. A magyar haderő technikai modernizációja miatt új feladatok keletkeznek, de ezek egyben új lehetőségek is a hazai védelmi ipar számára. A meglévő, korszerü e-learning eszközökre, valamint az élő, virtuális és konstruktív szimulációs rendszerekre építkezve bekapcsolódhatnak a nemzetközi vérkeringésbe, amivel segíteni tudják az interoperabilitási célok elérését.

Ahhoz azonban, hogy tudjuk merre kellene indulnunk, tisztában kell lennünk a jelenlegi helyzettel. A haderőfejlesztési program eredményeképpen az új haditechnikai eszközökkel új kiképzési eszközök, szimulátorok is érkeznek, ezzel jelentősen bővülni fog a kiképzéseknél alkalmazott szimulátorok száma. Magyarország csatlakozott az EU BattleLab ${ }^{14}\left(\mathrm{EDIDP}^{15}\right)$ és a CBRN SaaS ${ }^{16}$ (PESCO) projektekhez, valamint vezetője az EUROSIM ${ }^{17}$ (PESCO) projektnek.

Az USA-ban a szimulációs kiképzés támogatására jelenleg folyamatban van egy jelentős rendszer, a Synthetic Training Environment $\left(\mathrm{STE}^{18}\right)$ fejlesztése. A rendszer három fő részből fog állni: a Training Support System (TSS), a One World Terrain (OWT) és a Training Management Tool (TMT), amelyekkel a kiképzési szcenáriókat lehet létrehozni a modellezett környezetben, végre lehet hajtani a gyakorlásokat, majd értékelni lehet a végrehajtást. A tervek szerint az első ütemben (2023-2025-ig) csak a jelenlegi alkalmazott magas

\footnotetext{
${ }^{12}$ CAX: Computer Assisted Exercise / Számítógéppel támogatott gyakorlat.

${ }^{13}$ Molnár, Szabolcs 2020, 95-97.

${ }^{14}$ Az EU-Battle Lab (EDIDP) projekt célja olyan disztributív szimulációs képesség kialakítása, amely nyitott, moduláris, skálázható informatikai rendszer segítségével képes kapcsolódni a NATO-ban már alkalmazott szimulációs rendszerekkel. Az alkalmazási területek: oktatás és kiképzés, döntéstámogatás, kutatás. A projektben magyar oldalról a HM EI Zrt. vesz részt. Sikeres végrehajtás esetén egy prototípus, „demó” készlet és a szükséges dokumentáció fog elkészülni.

${ }^{15}$ EDIDP - European defence industrial development programme / Európai védelmi ipar fejlesztési program.

${ }^{16}$ A PESCO indítású EDA projektben Magyarország részéről a GAMMA Zrt és a BHE Kft vesz részt.

${ }^{17}$ Az Integrált Európai Összhaderőnemi Többcélú Kiképzési és Szimulációs Központ (EUROSIM) projekt célja egy európai uniós többnemzeti, összhaderőnemi müveletek szimulációs végrehajtására alkalmas rendszer kialakítása a tagországok haderöinek közös kiképzése és gyakoroltatása érdekében. A szimulációs rendszer fö eleme egy olyan információbiztonsági követelményeket kielégítő adatkapcsolat lesz, amely biztosítja, hogy a projektben résztvevő országok valós időben összekapcsolják a már müködő szimulációs központjaikat, kialakítva egy nemzetközi, összhaderőnemi kiképzés lehetőségét. A projekt Magyarország vezetésével, Franciaország, Lengyelország, Németország és Szlovákia részvételével, nemzetközi ipari együttműködés keretében kerülhet kialakításra 2025-re.

${ }^{18}$ Synthetic Training Environment / Szintetikus kiképzési környezet.
} 
rezsiköltségü, hosszú előkészítési idejű, kiképző központ centrikus élő és virtuális gyakorlatok felváltása történik meg. Az STE konstruktív szimulációs eleme csak a távoli jövőben (2032-ben) kerül megvalósításra, a jelenlegi JLCCTC ${ }^{19}$ rendszerhez (Warfighter's simulation /WARSIM). Az elkészülő virtuális és élő szimulációs részhez kapcsolódni lehet majd szabványos interfészeken keresztül, amikor a rendszer elkészül, célszerü lesz a MARCUS konstruktív szimuláció ezirányú fejlesztését végrehajtani.

\section{Egy korszerü CAX rendszer müködési követelményei napjainkban}

Magyarországon a nemzeti konstruktív szimulációs rendszer (és általában a szimulációs kiképzés modernizációjának) fejlesztési feladatait és ütemezését a Zrínyi HHP által meghatározott célokhoz kell igazítani. Ehhez szükség van a konstruktív szimulációs rendszerekkel szemben támasztott általános követelmények megfogalmazására. A követelmények komplexek, kiterjednek a gyakorló állományra, a rendszer továbbfejlesztésére és az üzemeltetés kérdéseire egyaránt.

A gyakorló és alájátszó állomány vonatkozásában a szimuláció biztosítsa CAX gyakorlatok megtartását a gyakorló parancsnokok és törzsek számára, amely terjedjen ki az elökészítés, megtervezés, végrehajtás és értékelés mozzanatokra is. A nemzetközi követelmények miatt fontos, hogy a rendszer képes legyen többfokozatú gyakorlatokon müködni század, zászlóalj, dandár, hadosztály és hadtest szinten. A szimulációs környezet biztosítsa a gyakorló állomány felkészítését a $\mathrm{NATO}^{20}$ eljárásmódok begyakorlására, az interoperabilitás fejlesztésére. A szimuláció biztosítson lehetőséget többnemzetiségü gyakorlatok végrehajtására. A harcászati helyzetek tartalmazzanak tetszőleges szervezeti felépítést, jármü, fegyver és szervezeti tulajdonságot, települési pozíciókat a harctéren, mind a saját erőkre, mind az ellenfélre, valamint az esetleges egyéb résztvevő felekre vonatkozóan, amelyeket a feladattervező egyszerúen és szabadon módosíthasson a kiképzés igényei szerint. Egy korszerü konstruktív szimuláció széles körűen és nagy részletességgel képes modellezni a hagyományos harctevékenységeket, a városharcot, a harctámogatást, felderítést, logisztikai ellátást, vegyivédelmet, a légi támogatást és légvédelmet, a tűztámogatást, elektronikai és kiberhadviselést, a nem háborús müveleteket, béketámogatást, katasztrófavédelmet, kritikus infrastruktúra védelmét, terrorizmus elleni harcot és határvédelmet.

A rendszer továbbfejlesztésénél fontos szerepe van a harcászati adatbázis naprakészen tartásának, valamint a harctér modellezésének folytonosságára. A harcászati/technikai adatbázisnak a NATO és nem NATO országok leggyakrabban használt katonai eszközeinek részletes müszaki adatait és képességeit kell tartalmaznia oly módon, hogy az állandóan módosítható és bővíthető legyen. A szimulációs tér alapmodelljét a digitális terepadatbázis képezi, amely a raszteres domborzati modellböl és a tereptárgyak/térkép alkotta részletes, nagy felbontású vektoros fedvényből áll. A terepadatbázis bővíthető különböző típusú, szabványos (NATO és nem NATO) formátumú adatbázisokból (például OpenStreetMap) ${ }^{21}$ a

\footnotetext{
${ }^{19}$ JLCCTC - Joint Land Component Constructive Training Capability / Összhaderőnemi Konstruktív Kiképzési Képesség Szárazföldi Komponense.

${ }^{20}$ NATO: North Atlantic Treaty Organization / Észak-atlanti Szerződés Szervezete.

${ }^{21}$ OpenStreetMap: Az OpenStreetMap egy világtérkép, amely szabad licenc alatt elérhető.
} 
világ bármely területéről, így alkalmassá tehető bármilyen müveleti terület modellezésére. A digitális terepadatbázis kiegészíthető legyen további szabványos formátumú raszteres rétegekkel, légifelvételekkel, müholdképekkel, szkennelt térképekkel. A modellezés vegye figyelembe a harctér és a rajta levő tereptárgyak tulajdonságait, a környezeti hatásokat (fényviszonyok, szél, eső, hó, hőmérséklet), ezek akár szélsőséges beállítását, és az emberi tényezőket (lefogás, felgyógyulás, fáradtság, kiképzettség szintje).

A szimuláció tervezésénél, végrehajtásánál és kezelésénél számos szempontot kell követni. A szimuláció rendelkezzen megszokott (Magyarországon Windows operációs rendszeren alapuló, de minősített kapcsolatot is biztosító) felhasználóbarát kezelői felülettel, de kapcsolódjon a más szimulációs vagy vezetési rendszerekhez is a szabványos NATO adatprotokollokon keresztül (HLA, ADatP-3, ${ }^{22} \mathrm{C} \mathrm{SIM}^{23}$ ). Legyen lehetőség adatcserére a talán legelterjedtebb két NATO informatikai rendszerrel (LOGFAS ${ }^{24}$ és TOPFAS). ${ }^{25}$ Használjon APP- $6^{26}$ harcászati jelrendszert a nagyfelbontású, digitalizált, vektoros és raszteres térképen, amelyen szabadon lehessen a gyakorló által készített vázlat-rétegeket be-, illetve kikapcsolni. A kezelői felületet az egyes operátori feladatokhoz lehessen igazítani, testre szabni (csak a szükséges interfész elemek, funkciók megjelenítése) a könnyebb betaníthatóság és kezelhetőség érdekében. Széleskörü funkcióival segítse a kiképzési szcenáriók kidolgozását, számítógéppel támogatott terepértékelés (láthatóság, járhatóság, terepmetszet) megjelenítését. Legyen képes kezelni előre betervezhető eseményeket (MEL/MIL27), amelyek automatikusan vagy gyakorlatvezetői segédlettel legyenek hatással a gyakorlatok végrehajtására. Tekintettel a nemzetközi alkalmazásra (NATO, EU) biztosítani kell, hogy a munkaállomások felhasználói felületét egyidejűleg különböző nyelvekre lehessen beállítani.

\footnotetext{
${ }^{22}$ ADatP-3 - Allied Data Publication 3, Nato Message Text Formatting System, technical standard about the construction of the messages. / Szövetséges Adat Publikáció 3, NATO üzenetek üzenetformátum rendszere, az üzenetek összeállításának müszaki szabványa.

${ }^{23}$ C2SIM: Standard for Command and Control Systems - Simulation Systems Interoperation, SISO-STD-0192020 / Vezetési és irányítási rendszerek és a szimulációs rendszerek együttműködésének szabványa.

${ }^{24}$ LOGFAS - NATO Logistics Functional Area Services (Logistics Systems) / Logisztikai Funkcionális Területi Rendszer, a NATO-ban használatos logisztikai információs és tervező program.

25 TOPFAS - Tools for Operations Planning Functional Area Services, NATO NC3A / Hadmüveleti Tervezést Segítő Funkcionális Területi Szolgáltatás, NATO Tanácsadó, Vezetési és Irányítási Ügynökség.

${ }^{26}$ APP-6 - Allied Procedural Publication 6, NATO Joint Military Symbology / Szövetséges Eljárási Publikáció 6: NATO Összhaderőnemi katonai jelek és jelzések.

${ }^{27}$ MEL/MIL: Master Events List/Master Incidents List / a gyakorlat fő esemény/incidens listája.
} 


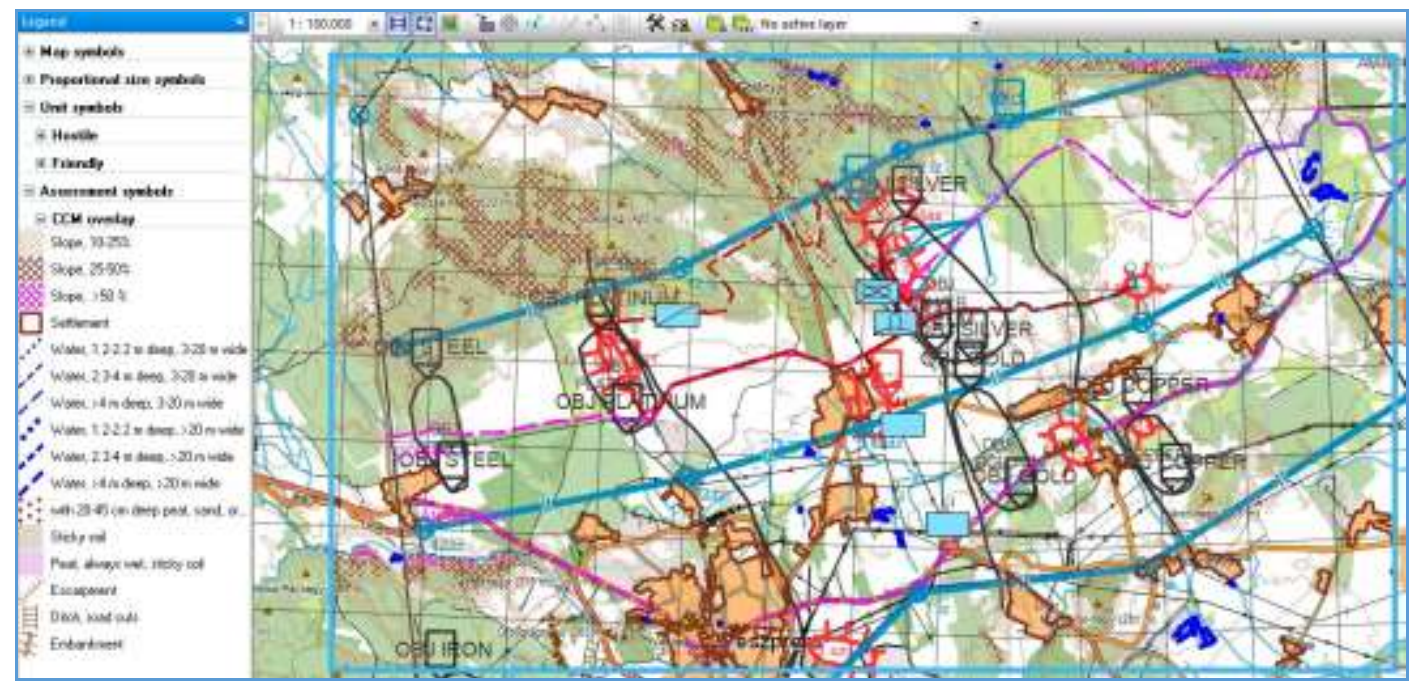

2. ábra.

MARCUS szimuláció terepértékelés (Cross-Country-Movement)

(Forrás: ARTIFEX kft., MARCUS_2020.pptx)

Végül a szimulátornak legyen beépített értékelő rendszere (AAR) ${ }^{28}$ amely biztosítja a gyakorlatok részletes mentését, az események keresését, visszajátszását, értékelését.

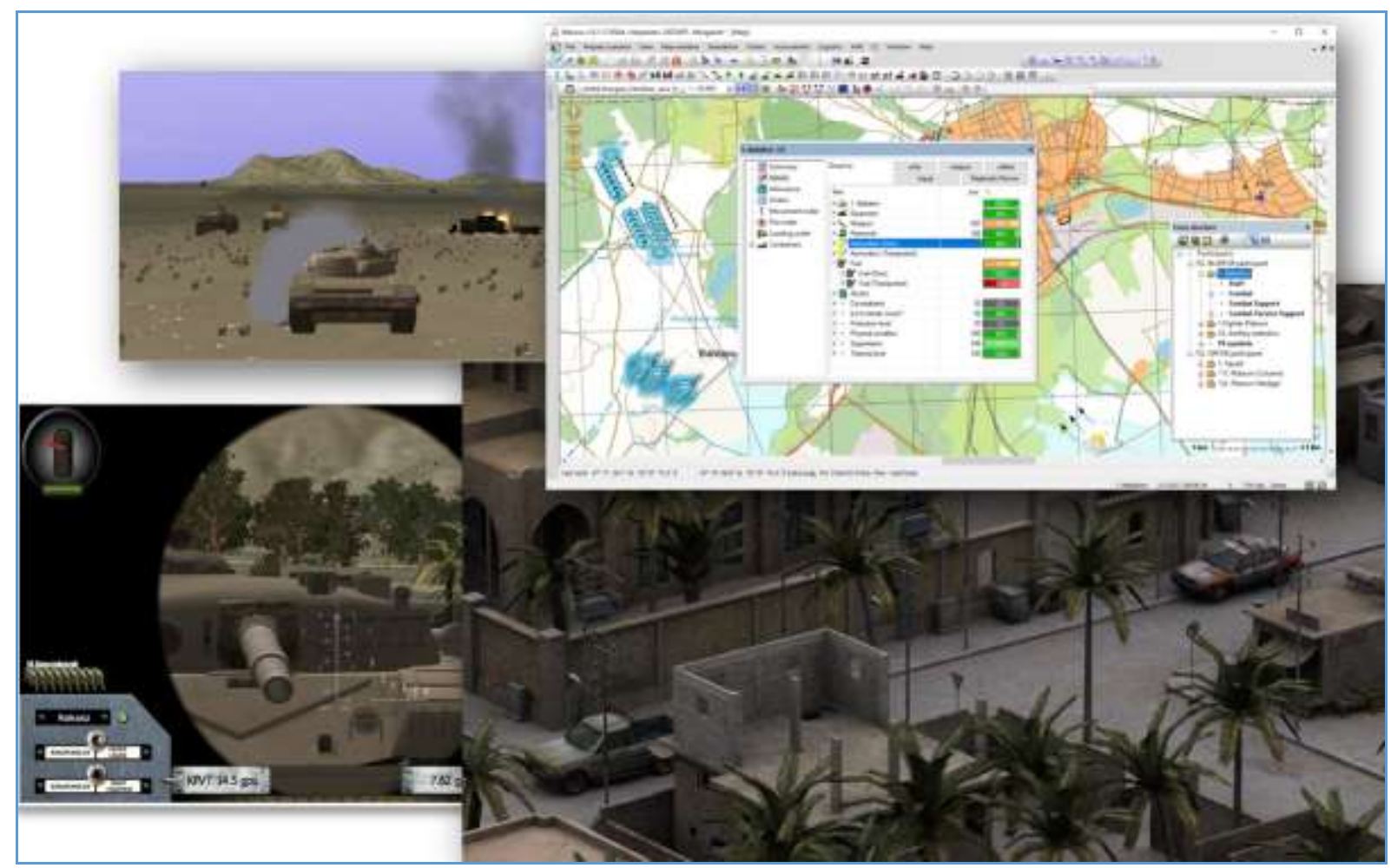

3. ábra.

MARCUS-KRONOS összekapcsolás HLA interfészen keresztül (forrás: ARTIFEX kft., ARTIFEX_2021.pptx)

\footnotetext{
${ }^{28}$ AAR - After Action Review / Gyakorlat utáni elemzés.
} 
A szimulációs rendszer hatékony müködtetéséhez szükség van a kezelö állomány felkészítésére, hogy önállóan legyenek képesek kezelni a felhasználói felületet. Ennek segítésére a szimulációs rendszer tartalmazzon oktatást támogató funkciókat, legyen lehetőség e-learning rendszerhez kapcsolódnia (legalább a NATO-ban használt keretrendszerhez). Figyelembe kell venni a gyakorlatok végrehajtását támogató technikai paramétereket (a támogató csoport létszáma ne haladja meg a 30 fớt, az alájátszói / operátori feladatok betanulása legfeljebb egy hétig tartson, megvalósítható legyen saját helyőrségben is, a frissítő képzés maximum 3 napot vegyen igénybe) is.

Az elmúlt években kialakult munkaerő piaci trendek és a csökkenő források/növekvő szükségletek miatt, a legtöbb korszerü CAX rendszert üzemeltető ország hadseregénél felmerült az igény a meglévö rendszerek korszerüsitésére, melynek egyik fontos eleme, hogy a meglévő rendszerek üzemeltetése jól tervezhető költség és humánerőforrás szintek mellett, akár saját üzemeltetéssel megoldható legyen. Ehhez nem csak az szükséges, hogy az üzemeltető hadsereg szakmailag jól felkészült, a rendszerek müködtetésére folyamatosan képzett kezelő állománnyal rendelkezzen, hanem a rendszereket úgy kell optimalizálni, hogy a feladatot kevesebb, eseti jelleggel végrehajtó kezelői létszámmal is müködtetni lehessen. Ehhez a gyártó/szoftverfejlesztö cégek, a központi szimulátor-müködtetö szakemberek és a gyakorlaton résztvevő helyőrségi állomány szoros együttmüködésére van szükség. A fejlesztő cégek - a folyamatos frissítések biztosítása mellett - állandó rendelkezésre állással biztosítják a folyamatos működéshez szükséges háttértámogatást, az esetlegesen felmerülő müszaki problémák kezelését, emellett végzik a központi üzemeltető állomány/kiképzők képzését/továbbképzését. A központi üzemeltető állomány feladata a központi és a mobilan telepíthető rendszerek üzemeltetése, helyőrségi állomány képzése, a helyőrség szinten jelentkező esetleges hiányok átmeneti megoldása. Nagy figyelmet kell fordítani a helyőrségi végrehajtó állományra, amelyben szükség van egy jól felkészített, kis létszámú központi kiképzés-technikai szimulátor üzemeltető csoportra és egy 2-3 fős kiképző részlegre, amelyet békeidőszakban minden helyőrségben létre kell hozni.

A felsorolt igények megvalósítása természetesen nem könnyü, több esetben a jogi helyzet, máshol a gazdaságosság teszi ezt nehézzé, de a modern szimulációs kiképzéshez szükség van egy ilyen követelményrendszer megfogalmazására.

\section{Üzemeltetési koncepcióváltás szükségessége az, MH Bakony Harckiképzö Központban}

Természetes, hogy a 20 évvel ezelőtt kialakított üzemeltetési technológiát már időszerü felülvizsgálni. A konstruktív szimulációs rendszer üzemeltetése kapcsán már induláskor olyan elvárások, célok jelentek meg, amelyek elérése és megvalósítása kiemelkedő fontosságú:

- általános költségmegtakarítási igény a szimulációs gyakorlatok üzemeltetésében,

- igazodás a NATO-ban elterjedt CAX kiképzési elvekhez,

- a nem túl magas kihasználtság miatti erőforrás lekötés optimalizálása,

- szakemberpótlási nehézségek megoldása (munkavállaló, nyugdíjas tisztek csekély száma),

- a csapatoknál történő saját üzemeltetés, 
- csapattisztek felkészítése külföldi szimulációs gyakorlatokban történő részvételre.

Ezen igények megválaszolása napjainkban is fontos, komplex feladat, amelyek végrehajtása a már meglévö képességek újra hasznositásával költséghatékony megoldás lehet.

A gyakorlatok végrehajtása során jelenleg nem a hivatásos alájátszói állomány kezeli a szimulációs rendszert, hanem a számítógépnél ülő civil operátor, aki a mellette ülő katonai alájátszó utasításai alapján viszi be a parancsokat. A jelenlegi üzemeltetési technológia az akkori idők informatikai kultúrájának figyelembevételével lett kialakítva, amely az eltelt évtizedekben sosem lett felülvizsgálva. Pedig az elmúlt évek tapasztalatai alapján célszerü megvizsgálni az alábbi felvetéseket:

- Az üzemeltetési rendszert célszerü átállítani a NATO-ban elterjedt CAX megoldásra, ahol a hivatásos katonai alájátszók kezelik a szimulációs rendszereket, nem a civil operátorok.

- A katonai alájátszók felkészítését a gyakorlat előtti napokban és a mini CAX során kell végrehajtani.

- Az üzemeltetés hátterét biztosító professzionális állomány korlátozódjon a tervezői, $\mathrm{OPFOR}^{29}$, DISTAFF $^{30}$ és AAR kezelői és a müszaki szakemberekre.

- A könnyebb kezelhetőség miatt az OPFOR állomány is csökkenthető néhány fővel.

- A Mars (MARCUS zászlóalj) rendszerek bekapcsolódása esetén 2 före kell csökkenteni a helyszíni támogató csoport létszámát.

Az új üzemelési renddel a Magyar Honvédség a NATO-ban manapság szokásos eljárásokat tudná alkalmazni a CAX gyakorlatok lefolytatása során. A tisztek megtanulnak szimulációs rendszert kezelni, így közvetlen kapcsolatba kerülnek a technológiával, amelyet külföldi gyakorlatok során is hasznosítani tudnak. A nemzetközi gyakorlatok megtartásának esélyei jelentősen megnőnek.

Az a megoldás már több gyakorlaton sikeresen vizsgázott. Például 2016-ban, a Brave Warrior gyakorlaton a MARCUS v12-es szimulációt Szlovéniában és Horvátországban is telepítették. A horvát helyszínen, pár napos betanítás után, már a horvát tisztek kezelték a MARCUS szimulációt. A betanítást a HM EI Zrt. és az ARTIFEX Kft. munkavállalóiból kialakított 5 fös csoport végezte. A végrehajtás tapasztalatai alapján ez a csoport a továbbiakban 2 före csökkenthető. A MARCUS szimuláció a felhasználók számára testre szabható, az alkalmazási terület (pl. tüzér, légierö, harckocsizó) szerint a felhasználói felület egyszerüsíthető, amely mind a betanítást, mind pedig a végrehajtást jelentősen segíti.

A tapasztalatok azt mutatják, hogy a CAX üzemeltetési technológia átdolgozásával jelentős hatékonyság-javulás érhető el, de az új feladatmegosztás kialakításához szükség van a feladatok átcsoportosítására, illetve a civil állomány létszámának csökkentésére.

\footnotetext{
${ }^{29}$ OPFOR - Opposition Forces / Ellenerők.

${ }^{30}$ DISTAFF - Directing Staff / Gyakorlatvezetőség.
} 


\section{1. táblázat.}

Javaslat a CAX gyakorlatok végrehajtásának feladatmegosżására

(Forrás: a szerző által összeállított táblázat)

\begin{tabular}{|c|c|}
\hline Résztvevö & Feladat \\
\hline MH Kiképzési Csoportfőnökség & változatlan \\
\hline MH alakulatai & katonai alájátszók biztosítása \\
\hline $\mathrm{BHK}$ & $\begin{array}{l}\text { az eddigi feladatkör kiegészül: } \\
\text { - } \quad \text { bizonyos létszámú katonai alájátszó biztosítása } \\
\text { - } \quad \text { tervezői és OPFOR feladatok végrehajtása }\end{array}$ \\
\hline HM EI Zrt. & $\begin{array}{ll}\text { - } & \text { müszaki üzemeltetés } \\
\text { - } & \text { részvétel az oktató csoportban } \\
\text { - } & \text { tervezői és OPFOR feladatokban közremüködés } \\
\end{array}$ \\
\hline Artifex Kft. & $\begin{array}{l}\text { - } \quad \text { részvétel az oktató csoportban } \\
\text { fejlesztői támogatás (müszaki felügyelet, } \\
\text { javítások, szoftver karbantartások, visszajelzések } \\
\text { gyüjtése, feldolgozása) } \\
\text { felhasználói igények alapján a rendszer } \\
\text { folyamatos továbbfejlesztése } \\
\text { közremüködés a nemzetközi szakmai } \\
\text { egyeztetéseknél, szakmai háttértámogatás }\end{array}$ \\
\hline
\end{tabular}

A gyakorlatban alájátszóként résztvevő hivatásos katonai állomány felkészítésének tematikáját és a képzés személyi feltételeit ki kell alakítani. A felkészítés történhet Várpalotán, vagy az alakulat helyőrségében. A BHK állományát fel kell készíteni arra, hogy az eddiginél intenzívebben vegyen részt a szimulációs gyakorlatok végrehajtásában. A gyakorlatok tervezése során be kell tervezni a katonai alájátszók felkészítését. Ehhez célszerü a MARCUS szimulátort olyan irányban is fejleszteni, hogy könnyebb legyen a használata (felhasználói felület egyszerüsítése, intuitív funkciók bővítése).

$\mathrm{Az}$ átalakításokkal a szimulációs rendszerek üzemeltetését jelenleg biztosító civil állomány létszáma drasztikusan csökkenthető, a bevezetés utáni 4. hónaptól 35 fö, majd a 6. hónaptól 20 fó is képes lesz a teljes rendszert felkészíteni a gyakorlatokra, illetve a gyakorlatok végrehajtása során támogatni a hivatásos alájátszói állományt. A tapasztalatok alapján még további létszámcsökkentés is elképzelhető.

\section{2. táblázat.}

Várható alájátszó létszámok csökkentésének lehetöségei (elöttelüj rendszernél várható) (Forrás: a szerzö által összeállitott táblázat)

\begin{tabular}{|c|c|c|c|c|c|c|c|c|}
\hline Gyakorlat & $\begin{array}{l}B L U E F \\
O R\end{array}$ & OPFOR & $\begin{array}{l}3 . \\
\text { fél }\end{array}$ & Mars & Mars & Mars & $\begin{array}{l}\text { Össze } \\
\text { sen }\end{array}$ & $\begin{array}{l}\text { Csökke } \\
\text { nés }\end{array}$ \\
\hline $\begin{array}{l}\text { Bocskai fokos } \\
2010\end{array}$ & $23 / 5$ & $10 / 9$ & & & & & $33 / 14$ & 19 \\
\hline Decon 2011 & $24 / 5$ & $6 / 5$ & & & & & $30 / 10$ & 20 \\
\hline Acélpenge 2012 & $12 / 3$ & $8 / 6$ & $4 / 2$ & $5 / 2$ & & & $29 / 13$ & 16 \\
\hline Pegazus & $6 / 1$ & $2 / 2$ & & $5 / 2$ & & & $13 / 5$ & 8 \\
\hline
\end{tabular}




\begin{tabular}{|c|c|c|c|c|c|c|c|c|}
\hline Decon2012 & & $12 / 9$ & & $9 / 2$ & $7 / 2$ & $6 / 2$ & $34 / 15$ & 19 \\
\hline Jeges Tisza & $14 / 4$ & & & & & & $14 / 4$ & 10 \\
\hline $\begin{array}{l}\text { Bocskai fokos } \\
2012\end{array}$ & & $11 / 8$ & & $9 / 2$ & $7 / 2$ & $6 / 2$ & $33 / 14$ & 19 \\
\hline $\begin{array}{l}\text { Logisztikai } \\
\text { rendszergyakorlat } \\
2009\end{array}$ & $28 / 5$ & $2 / 2$ & $1 / 1$ & & & & $31 / 8$ & 23 \\
\hline Sötét felhö 2012 & $9 / 3$ & $7 / 6$ & & & & & $16 / 9$ & 7 \\
\hline Black Horse 2014 & $18 / 4$ & $1 / 1$ & $1 / 1$ & & & & $20 / 6$ & 14 \\
\hline
\end{tabular}

A felszabaduló állomány bértömege nem a szimulációs kiképzést terheli, azonban a gyakorlatokban több éve résztvevő munkavállalók egyéb kiképzési területen hasznosíthatók (például a most szervezés alatt álló EUROSIM PESCO projektben).

\section{Folyamatban lévö fejlesztések}

Az elmúlt évben a CAX rendszerekhez kapcsolódóan elindult a MARCUS szoftver következő generációjának (MARCUS v20) fejlesztése, amely a felhasználói igények alapján nem csak új képességekkel, hanem még költséghatékonyabb müködtetés lehetőségével is rendelkezik majd.

A fejlesztési feladatok első üteme (2020-2022) azon legfontosabb területeket célozza, amelyekben az elmúlt években a szimulációs rendszer képességeinek korszerüsítése, bővítése nem követte a felhasználói igények és a változó környezet indokolta célokat. Folytatni kell az interoperabilitás terén eddig elért eredmények mentén a nemzetközi együttműködést más szervezetekkel, rendszerekkel (SIM ${ }^{31}$-SIM és SIM-C2 kapcsolat). A modernizáció során a felhasználók által beszerzett új technikai eszközökkel ki kell bővíteni a szimulációt (ha azok még nem léteznek a szimulációban). Ha az eszközhöz érkezik trenazsőr berendezés, azokat össze kell kötni a meglévő szimulációs rendszerekkel.

A fejlesztés továbbra is kiemelten célozza a szimuláció kezelésének és üzemeltetésének még fokozottabb egyszerüsítését. Mind hazai, mind külföldi viszonylatban is fontos, hogy minél kevesebb kezelővel, minél nagyobb kiterjedésű gyakorlatokat lehessen végrehajtani. A költséghatékony üzemeltetés érdekében további fejlesztéseket lehet megvalósítani, amelyek nagyon rövid időn belül tovább növelik a gazdaságos üzemeltetés lehetőségét. Az új MARCUS verzió már a fenti üzemeltetési elveknek megfelelően került kialakításra.

\footnotetext{
${ }^{31}$ SIM - Simulation / Szimuláció.
} 


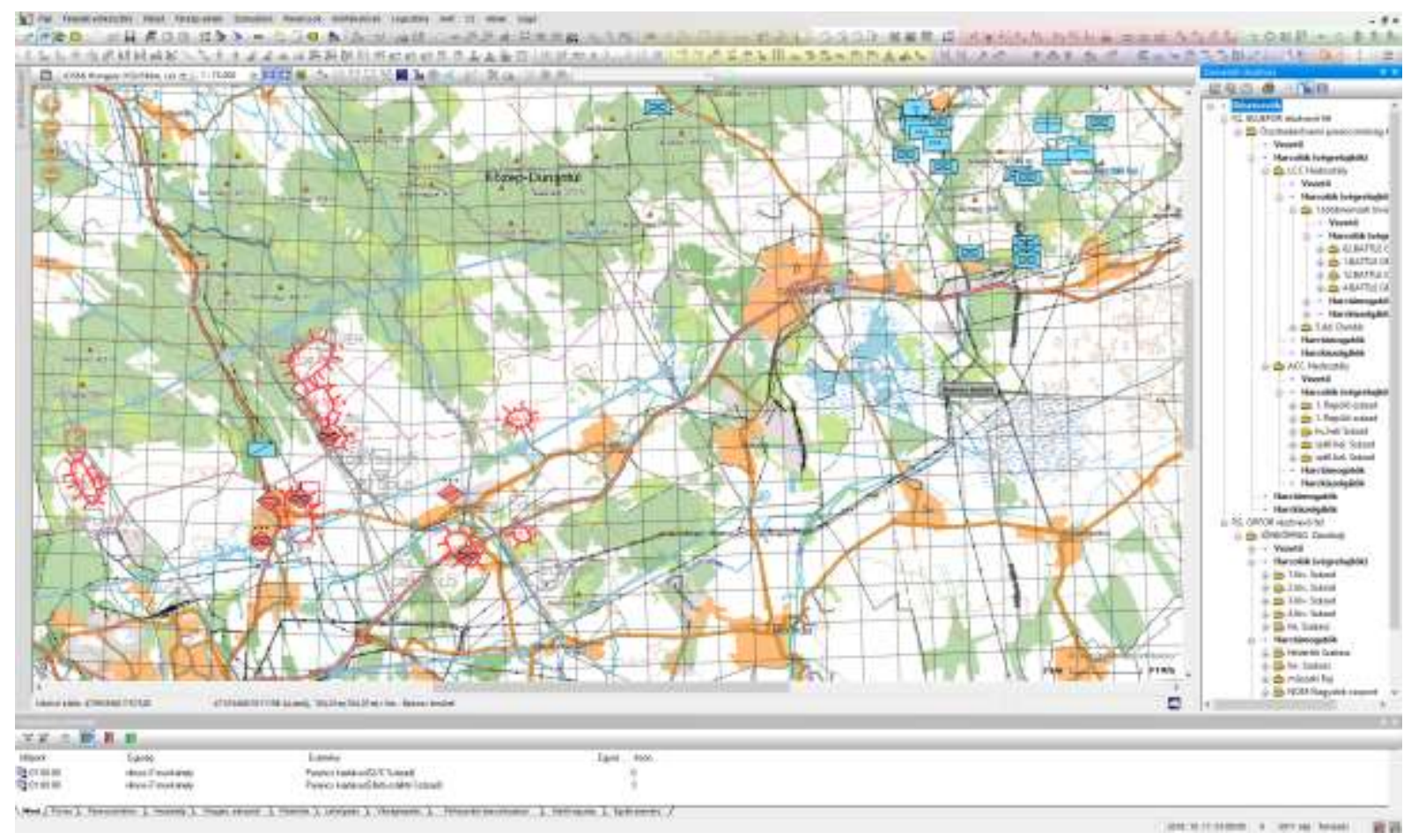

4. ábra.

MARCUS szimuláció kezelöi felület

(Forrás: ARTIFEX Kft archívum)

A NATO több területen támogatja, sőt elvárja a nemzeti rendszerek együttmüködését. Ezen belül a szimuláció-szimuláció és a szimuláció-vezetési rendszer kapcsolatok megoldása alapvető fontosságú, mivel a szimulációs gyakorlatok végrehajtása csak ezen informatikai rendszerek kapcsolódása esetén teremt valósághü környezetet.

Kitüzött cél, hogy a már integrált nemzeti fejlesztésű szimulációs rendszerek (MARCUS, MARS, KRONOS) összekapcsolhatók legyenek a Magyarországon már megtalálható (például FABV Trainer, ${ }^{32}$ Elektronikai hadviselés szimulátor szakkabinet) ${ }^{33}$ és a NATO-ban (például JCATS, WARSIM) használt katonai vagy katasztrófavédelmi célú (például Building EXODUS $^{34}$ ) szimulációs eszközökkel. Ennek érdekében a HLA munkacsoport által kidolgozott NETN FOM ${ }^{35}$ alkalmazása és további interoperabilitási tesztekhez újabb partnerek keresése és a HLA ${ }^{36}$ képesség fejlesztése folyamatos feladatként jelenik meg.

\footnotetext{
32 A Magyar Honvédség VS BTR 80 vegyifelderítő járműveinek kezelöi számára kifejlesztett oktató rendszer. Fejlesztője a GAMMA Műszaki Zrt, Magyarország meghatározó védelmi ipari cége, jelenleg a legszélesebb védelmi ipari termékportfólióval rendelkező magyar cég.

${ }^{33}$ A Honvédelmi és Haderőfejlesztési Program keretében indított elektronikai hadviselés fejlesztés részeként az NKE HHK Elektronikai Hadviselés Tanszékén kialakított laborban korszerü eszközökön sajátíthatók el a rádióelektronikai felderítés és zavarás módszerei.

${ }^{34}$ Fire Safety Engineering Group (The Faculty of Architecture, Computing \& Humanities, UNIVERSITY of GREENWICH) által kifejlesztett kiürítési szimulációs program (EXODUS), épületek kiürítési szimulációjához, gyalogosok dinamikus viselkedéséhez, forgalmának analíziséhez egyaránt használható.

${ }_{35}$ NETN FOM - NATO Education and Training Network Federate Object Model, NATO MSG-068 Working Group / NATO Oktatási és Kiképzési Hálózat Szövetségi Objektum Modell, NATO MSG-068 munkacsoport

${ }^{36}$ HLA - High Level Architecture. A HLA az a képesség, hogy a különböző számítógépeken futó, helyben vagy széles körben elterjedt szimulációkat összekapcsoljon, függetlenül az operációs rendszerüktől és a megvalósítási nyelvüktöl.
} 


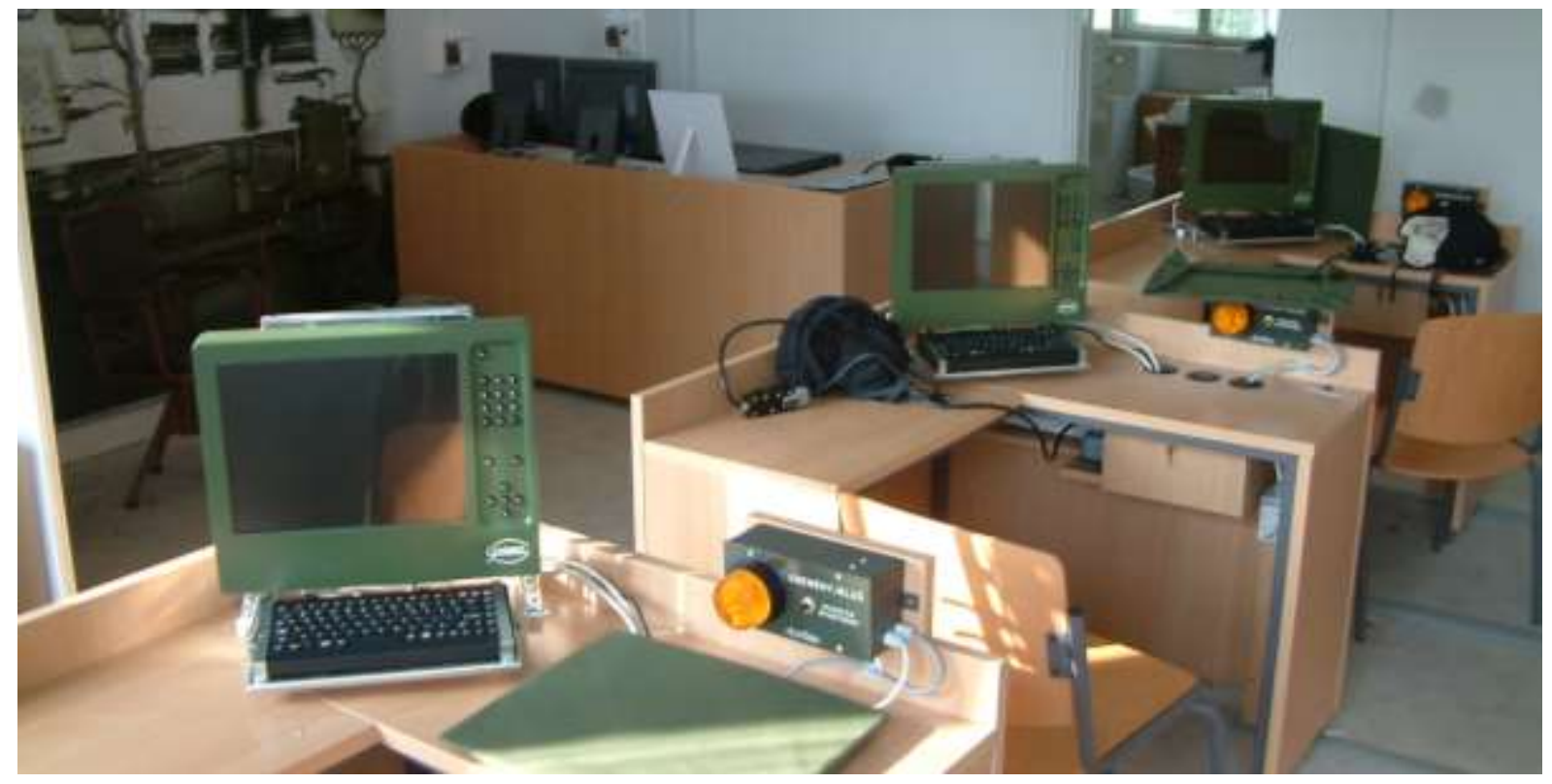

5. ábra.

FABV Trainer oktató terem az MH 93. Petöfi Sándor Vegyivédelmi Zászlóaljnál

(Forrás: GAMMA Műszaki Zrt archívum)

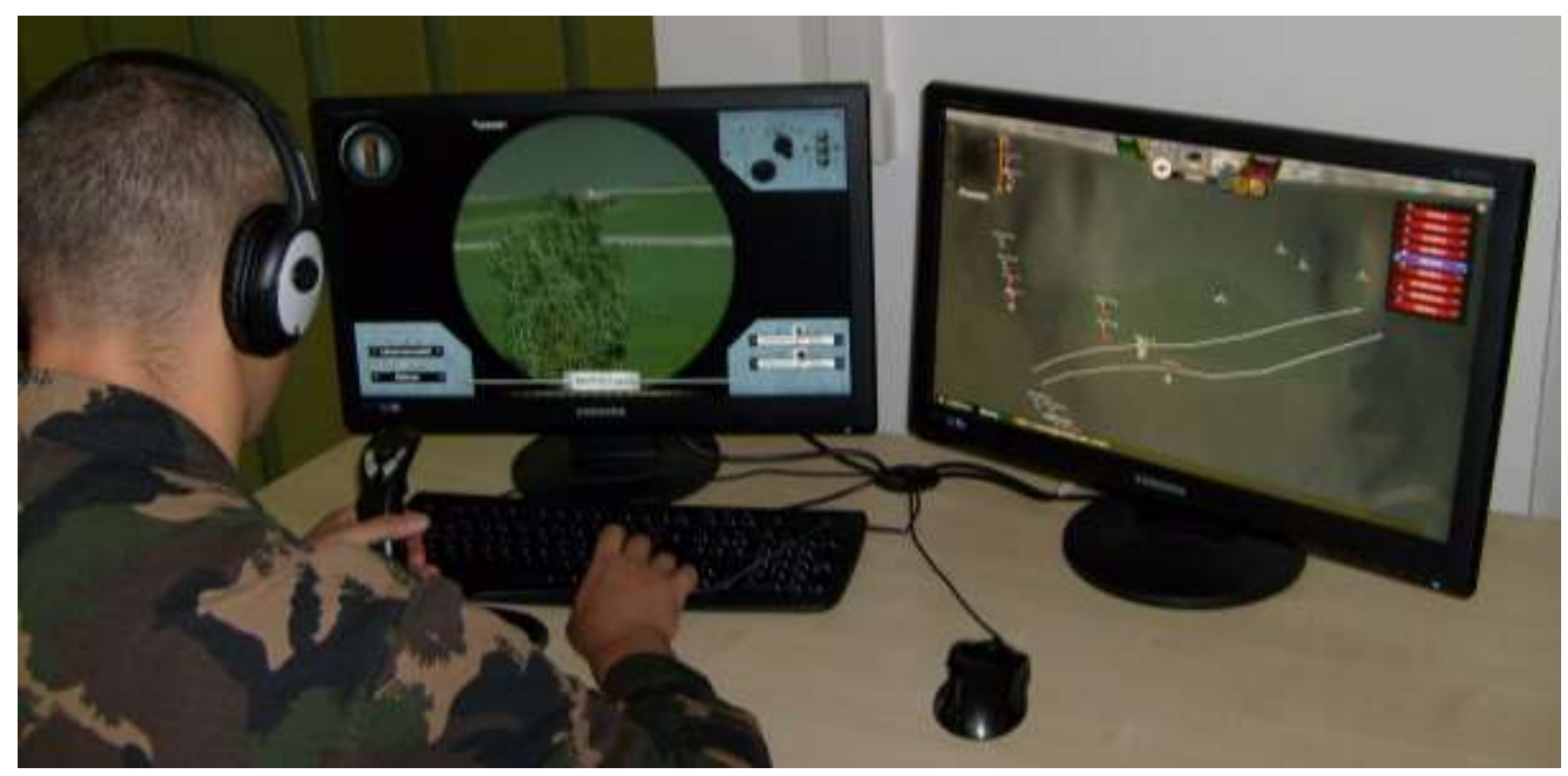

6. ábra.

KRONOS rekonfigurálható szakaszszintü szimulátor egy munkaállomása

(Forrás: ARTIFEX Kft archívum)

A CWIX $^{37}$ gyakorlatokon eddig elért eredmények alapján (CWIX tesztek más NATO nemzetek $\mathrm{C} 2$ rendszereivel) rendelkezésre áll a technológia, hogy MARCUS szimuláció C2

${ }^{37}$ CWIX - Coalition Warrior Interoperability eXploration, eXperimentation, eXamination, eXercise / Koalíciós harci együttmüködés kutatása, kísérletek végzése, ellenőrzése, gyakoroltatása. 
rendszerekkel adatcserét hajtson végre, és képes legyen a $\mathrm{C} 2 / \mathrm{C}_{4} \mathrm{I}^{38}$ rendszerek stimulációjára. A nemzetközi adatcsere után meg kell valósítani a magyar fejlesztésü C2 rendszer és a szimuláció összekapcsolását is.

A szimulációs gyakorlatok végrehajtásának támogatására az NCIA ${ }^{39}$ beindította az EXIS $^{40}$ projektet, ami új nevet kapott: NISE ${ }^{41}$. A munkát a JFTC ${ }^{42}$ koordinálja. A munkába meghívták a MARCUS-t fejlesztő magyar céget ${ }^{43}$ is.

A kiképzési szolgáltatás hatékonyságát növelheti, ha nem csak fix telepítésü munkaállomásokon lehet gyakorolni, hanem akár konkrét hadgyakorlatok mellé kitelepített mobil szimulátor pontokon is. Erre a célra az egyik leghatékonyabb megoldás a Védelmi Mobil Szimulátor Központ (VMSzK) kialakítása, ahol a MARCUS új változata már úgy lett kialakítva, hogy egy mobil környezetben, skálázható méretekben is optimálisan müködtethető legyen. A demonstrációs eszköz az Irinyi Terv iparstratégiai támogatásai előirányzatból finanszírozott „Irinyi Terv iparstratégiai támogatásai program 2019” segítségével a GAMMA Zrt által fejlesztett, több célú, bővíthető alapterületű konténercsalád egyik elemében kerül megvalósításra. Az eszköz szabványos méretű konténerszállító eszközökkel mozgatható és a végleges alapterületre a bevetés helyszínén könnyen kibővíthető.
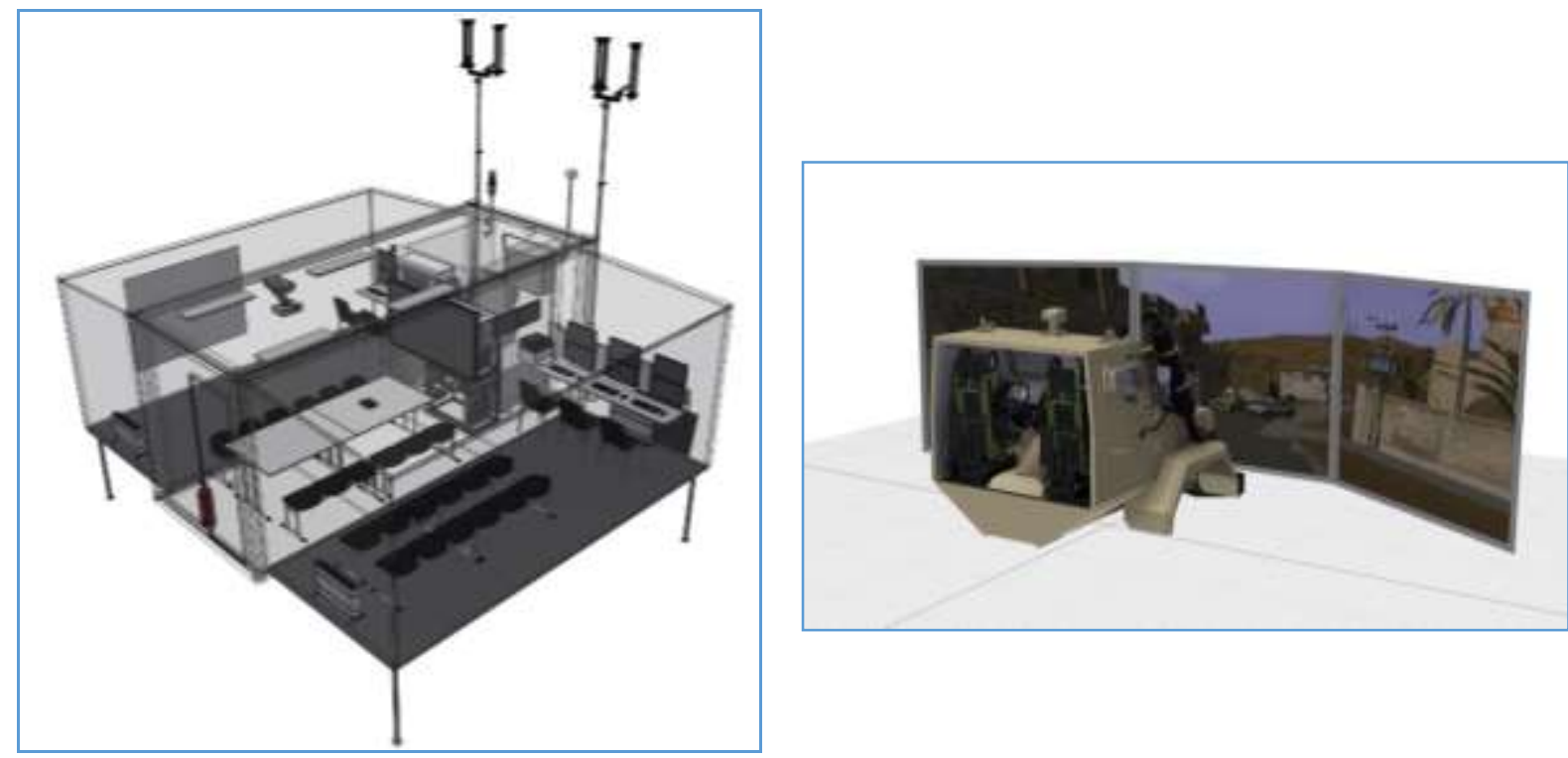

7. ábra.

A több célú, bövíthetö alapterületü konténer és egy GAMMA-Artifex jármüvezetö kiképző szimulátor látványterve

(Forrás: GAMMA Müszaki Zrt archívum)

\footnotetext{
${ }^{38}$ C2/C4I: Command and Control / Command, Control, Communications, Computers, Intelligence / Vezetés, irányítás, kommunikáció, számítógépek, hírszerzés.

${ }^{39}$ NCIA: NATO Communications and Information Agency / NATO Híradó és Informatikai Ügynökség.

${ }^{40}$ EXIS: NATO Exercise Information System / Gyakorlat Információs Rendszer.

${ }^{41}$ NISE: NATO Information Service for Exercises, NCIA / NATO Információs Rendszer Gyakorlatok számára.

42 JFTC - Joint Forces Training Centre / NATO Összhaderőnemi Kiképző Központ, Bydgoszcz, Lengyelország.

${ }^{43}$ A rendszert az Artifex Szimulációs és Kiképzési Rendszerek Kft. fejleszti. A cég 1989 óta foglalkozik katonai szimulációs és oktatási rendszerek fejlesztésével. A kifejlesztett eszközök az egyéni kiképzéstől (KRONOS) a hadtest szintü törzskiképzési rendszerekig (MARCUS) terjednek.
} 
A szimulációs kiképzéseknél a konstruktív és virtuális szimulációnál egyaránt szükség van mobil rendszerekre, mint ahogyan a lőkiképzés területén is. Konstruktív szimulációt lehet alkalmazni nem katonai (rendvédelem, katasztrófavédelem, terrorizmus, kritikus infrastruktúra védelme) területen is, de az üzemeltetés nyilvánvalóan katonai közremüködéssel történhet. A virtuális szimuláció kiválóan felhasználható önkéntes tartalékos kiképzés támogatására (egyes harcos kiképzésre, kisalegységek harcászati feladatainál, országos szinten), mint ahogyan a mobil lőtér is. Jellegéből adódóan az eszköz kihasználtsága maximalizálható, az egyes gyakorlatokra vetülő költség jelentősen csökkenthetö, a megtérülési ráta igen magas. A kialakítandó konténeres szimulációs rendszer alapjain további kiképzési rendszerek is megvalósíthatók.

Ezen kiképzési kultúra megvalósulása megteremti annak lehetőségét, hogy a rendszert „exportálni” lehessen a környezö és más NATO/EU tagországokba. A projekt illeszkedik az EUROSIM és az EU Battle Lab EDIDP projektekben meghatározott célokhoz.

A MARCUS hosszú távú fejlesztése (2022-2026) a nagyobb munkákat igénylő feladatrendszer és a stratégiailag fontos területek még pontosabb lefedését célozza meg. A folyamatosan fennálló migrációs fenyegetés, a világszerte tapasztalható polgárháborús helyzetek, a missziós feladatok, a nem csituló terrorizmus, a kiberbünözés és a fejét időről-időre felütő járványhelyzet is indokolja az ezekre a feladatokra történő kiképzés továbbfejlesztését. A kihívások mellett rendkívül fontos a felhasználók és az üzemeltetők igényeinek, észrevételeinek folyamatos követése és megvalósítása a szimulációs rendszerben.

A jelenlegi geopolitikai helyzetben gyakorlatilag minden NATO müvelet civil környezetben történik, amelyet a kiképzés során is meg kell jeleníteni. A MARCUS szimuláció jelenleg is alkalmas civil mozzanatok megjelenítésére/bejátszására, de az intenzív civil környezet (civil repülőgépek, hajók, gépjármüvek és személyek mozgása) csak úgy valósítható meg, ha kezelői beavatkozás nélkül, vagy csekély beavatkozással, mesterséges intelligencia generálja azt automatikusan a virtuális térbe.

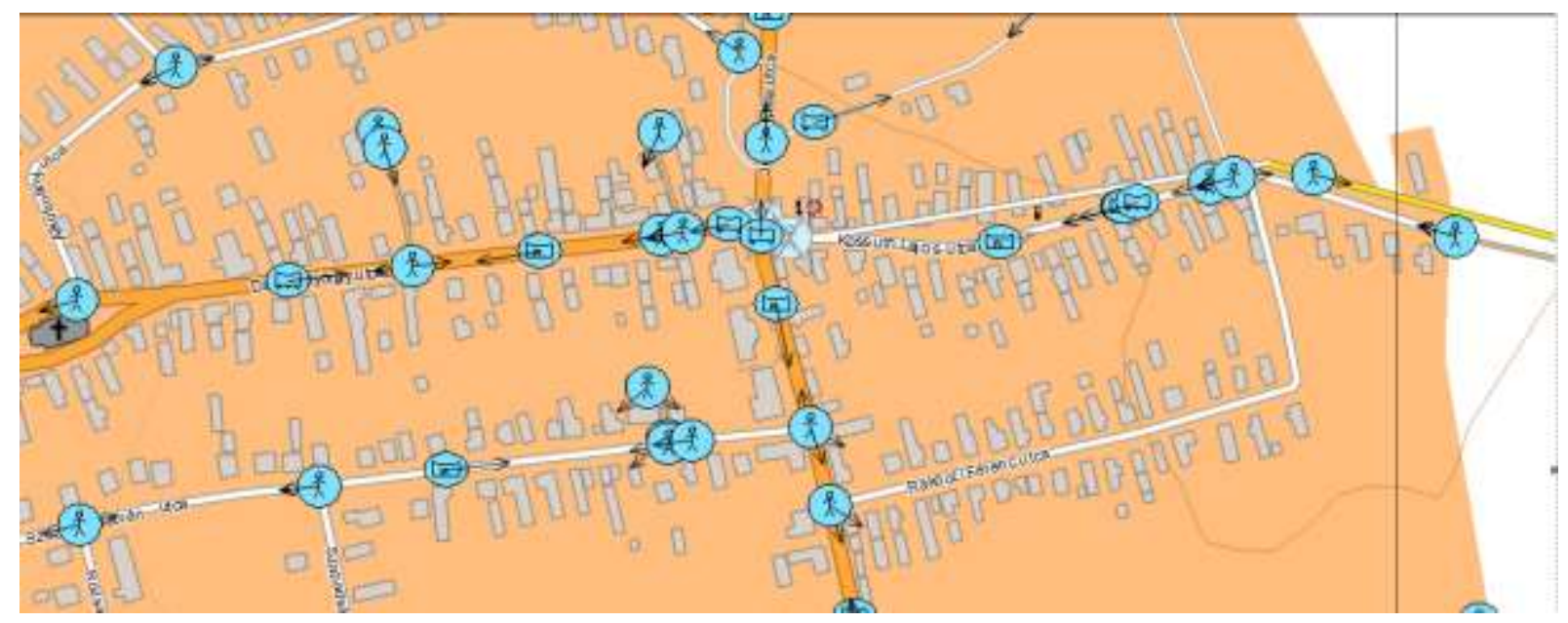

8. ábra.

Mesterséges intelligencia által generált, eseményekre reagáló civil környezet (robbanás utáni menekülés, segélynyújtók helyszínre indulása)

(Forrás: ARTIFEX Kft. MARCUS v14 kezelési utasítás.docx) 
Korunk aktuális kihívásaira (migráns helyzet, terrorizmus) történő hatékonyabb felkészítés érdekében tovább kell bővíteni a meglévő szimulációs modelleket (például táborok müködtetése, csoportok összeállítása, kezelése, határvédelmi eszközök, speciális terrorelhárító eszközök, robbanószerek, bombák emberre és környezetre gyakorolt hatása, tömeges átvizsgálás, robbantás, vegyi anyagok alkalmazása metróban, zárt helyen, kibertámadások elleni védelem) A végrehajtott szimulációs gyakorlatok során rengeteg katonai és üzemeltetői visszajelzés keletkezik. Ezek egy jelentős része továbbfejlesztési javaslatként is értelmezhető.

\section{A szimulációs központ felhasználásának lehetőségei a nemzeti szimulációs képesség kialakitására}

A NATO átlagszint elérése érdekében Magyarországon a meglévő szimulációs képességek továbbfejlesztése szükséges, aminek egyik módszere lehet olyan nem katonai szervezetek bevonása a szimulációs kiképzésbe, amelyek eddig nem, vagy csak igen szórványosan müködtek közre az MH gyakorlatai során. Az MH képesség bővülése lehetőséget terem a rendvédelmi szervek, önkormányzatok és ipari szereplők hatékony felkészítésének támogatására, ezzel nem csak a katonai értelemben vett országvédelem valósulhat meg, hanem a katasztrófahelyzetek kezelése és a kritikus infrastruktúravédelem kapcsán érintett összes közreműködő hatékony felkészítése.

Ezért az egyik hosszú távú fejlesztési lehetőség lehet a Katonai Szimulációs Központ kiajánlása az országon belül az állami szervek, rendvédelmi, fegyveres testületek, önkormányzatok, polgári és ipari szereplők részére, mert nem rendelkeznek szimulációs kiképzési eszközzel. Nincs olyan gyakorlási környezetük, amelyben az elképzelt helyzetet objektív környezetben, emberi tényezők nélkül tudnák megtervezni, végrehajtani és értékelni. A „nemzeti védelmi képességünknek” a katonai erő nagyon fontos része, de nem a teljessége. Súlyos országos katasztrófa vagy külső támadás esetén minden érintett fél együttmüködésére szükség van, így ezen szervezetek kiképzése is elhagyhatatlan. A rendszer alkalmazható lenne többek között a jelenleg csak a Marathon Terra ${ }^{44}$ rendszert alkalmazó helyi vagy központi katasztrófavédelmi gyakorlatoknál is.

Egy másik fejlesztési cél lehet a mobil szimulációs kiképzési szolgáltatási képesség kialakítása.

A nemzeti szimulációs központ és kiképzési képesség kiajánlása mellett szükség lenne egy mobil szimulációs kiképzőcsoport felállítására. A csoport rendelkezne a korábban említett kinyitható 3x20 lábas konténerrel, a gyakorlatok végrehajtásához szükséges infrastruktúrával (szerverek, OPFOR és DISTAFF munkahelyek, hálózati elemek). A telepítési helyszínen az alájátszói munkahelyeket a szolgáltatást igénybe vevő fél szolgáltatja, amelyek csatlakoznak a mobil rendszerre. A kiképző csoport végrehajtja az alájátszók és a gyakorlók kiképzését is.

\footnotetext{
${ }^{44}$ Marathon Terra - A Rácz Zoltán által fejlesztett Marathon Terra a BM és alárendelt intézményeinek, valamint együttmüködő szervezeteinek regisztrált munkatársai között a meglévő e-mail rendszerektől független, megbízható, méret és fájltípus korlátozás nélküli informatikai összeköttetését, kapcsolattartását biztosító rendszer, amelyet a gyakorlatok során is alkalmaznak.
} 
A nemzetközi trendek alapján fontos lenne a HUN-LVC SIM ${ }^{45}$ képesség kialakítása, amikor a nemzetek saját eszközeik felhasználásával komplex, integrált rendszernek tekinthető kiképzési eszközt hoznak létre (LVC SIM). Ezen a területen az USA jár legelöl, de több más NATO tagország is szép eredményeket ért el. Az LVC kialakítása nem csupán egy infrastruktúra fejlesztés, a hozzá tartozó kiképzési rendszert is ki kell dolgozni. A rendszer létrehozása lehetővé teszi többszintü szimulációs gyakorlatok végrehajtását. A jelenleg használt rendszerek közül pillanatnyilag a MARCUS, KRONOS és a Békefenntartó Felderítő Szimulátor ${ }^{46}$ (prototípus) képesek együttmüködni egy közös szimulációs gyakorlaton.

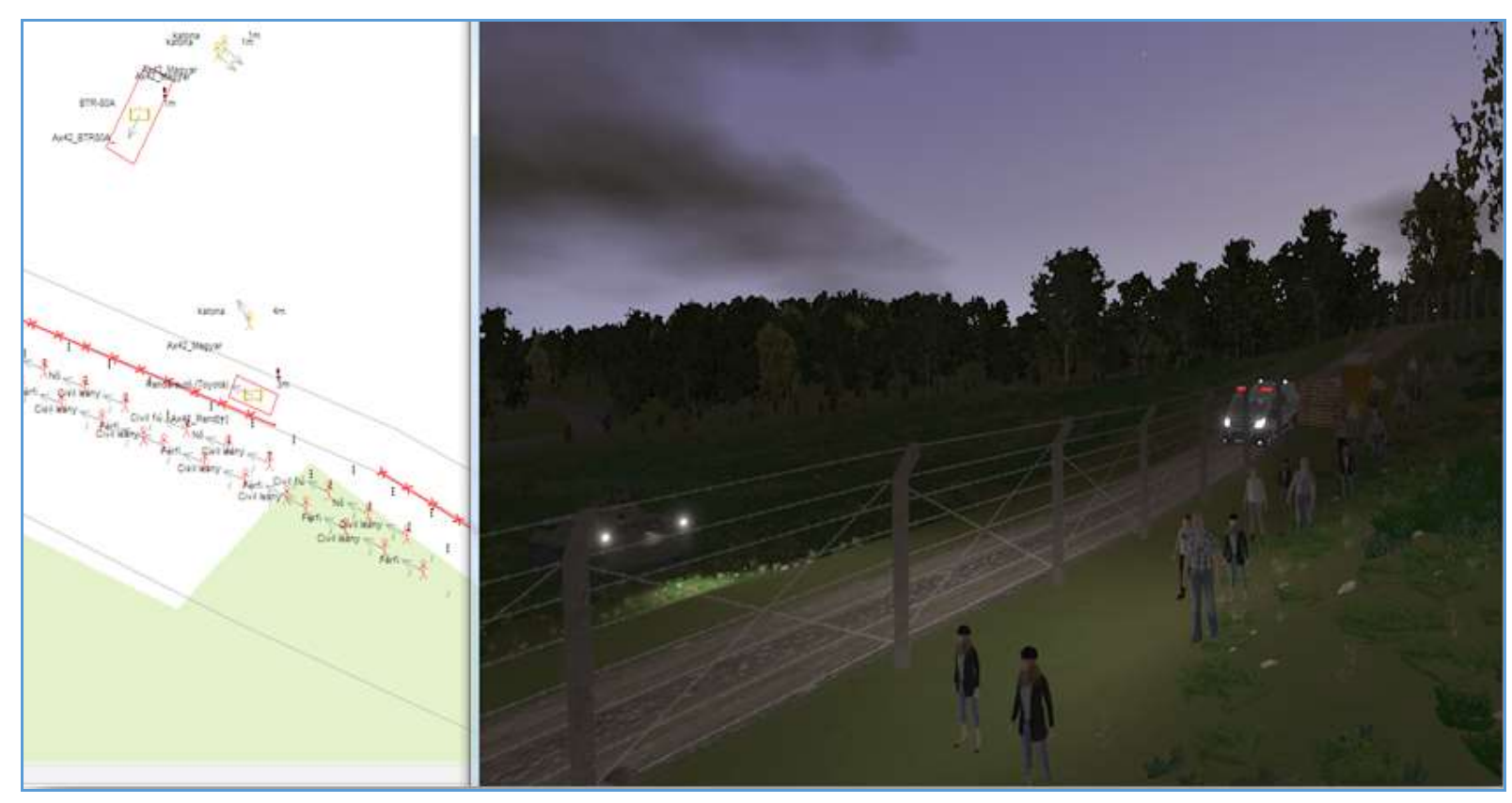

9. ábra.

MARCUS alapú Békefenntartó Felderitó Szimuláció

(Forrás: ARTIFEX Kft., Békefenntartó Felderítő Szimulátor kezelési utasítás.docx)

Más nemzetek példája mutatja, hogy a szimulációs rendszerek összekapcsolásával párhuzamosan, a vezetési rendszerek és a szimulációs tér összekapcsolása is zajlik. Erre a feladatra különböző kommunikációs felületek alkalmazhatók (szimulátorok között: HLA Evolved, DIS, ${ }^{47} \mathrm{C} 2 / 4$ rendszerek felé: ADatP-3, MIP,${ }^{48} \mathrm{C}-\mathrm{BML}^{49}$ és a NCIA NISE).

\footnotetext{
${ }^{45}$ LVC SIM - Live-Virtual-Constructive Simulation / Élő-Virtuális-Konstruktív Szimuláció együttmüködése ${ }^{46}$ Az ITM pályázat keretében elkészült Békefenntartó Felderítő Szimulátor prototípus, amely a járőrök kiképzésére alkalmas. A rendszer nagyon hasonlít a GAMMA által fejlesztett FABV trenazsőrre. Egy munkahelyen ül a soför és a jármü/járőr parancsnok. 3D és digitális térkép segítségével több járör tud egy hálózatban gyakorolni, ezen felül kialakításra került egy „parancsnoksági” munkahely. A kommunikáció szimulált rádióhálón történik.

${ }^{47}$ DIS - Distributed Interactive Simulation $(D I S)$ is an IEEE standard (IEEE 1278-1993, DIS 7: IEEE 1278.12012) / Elosztott interaktív szimuláció, IEEE szabvány (IEEE 1278-1993, DIS-7: IEEE 1278.1-2012).

${ }^{48}$ MIP - Multilateral Interoperability Programme / Többoldalú Interoperabilitási Program.

49 C-BML - SISO-STD-011, "Standard for Coalition Battle Management Language Phase 1" / Koalíciós csoportok harci irányítási folyamatainak leírására szolgáló nyelv, 1 fázis.
} 


\section{A fejlesztések nemzetközi lehetőségei}

A hazai megoldáshoz hasonlóan a Szimulációs központ kiajánlható nemzetközi szinten is. Bár minden NATO tagország alkalmaz szimulációs kiképzési rendszereket, a tagországok közül mindössze Magyarország, Németország és Franciaország rendelkezik saját nemzeti fejlesztésü CAX kiképzési háttérrel. A többi nemzet túlnyomórészt amerikai rendszereket használ, ami miatt az üzemeltetés, a testre szabás és a továbbfejlesztés egyaránt komoly müszaki, anyagi és adminisztratív kihívásokkal jár.

Az igen elterjedt JCATS és JTLS ${ }^{50}$ rendszereknek hivatalos NATO bejelentés szerint sincs jövöjük, ezeket le kell cserélni pár éven belül. Ebben a helyzetben Magyarország komoly helyzeti előnybe került, amelyet célszerü lenne kiaknázni. Mivel a BHK lö- és gyakorlóterülete adottságai miatt jelentős külföldi gyakorló állományt vonz a helyszínre, az éles gyakorlatok végrehajtását össze lehetne kötni szimulációs gyakorlatok végrehajtásával is (nyújtott szolgáltatásként). Célszerü lenne ezen képesség/szolgáltatás megvalósíthatóságának vizsgálata, mind a képesség, mind a szükséges beruházások és a gazdaságossági szempontok mentén.

A nemzeti szimulációs központ és kiképzési képesség nemzetközi kiajánlása mellett lehetőség van egy mobil, kitelepülő szimulációs kiképzőcsoport felállítására. A csoport rendelkezne a korábban említett kinyitható 3×20 lábas konténerrel, berendezve a gyakorlat végrehajtásához szükséges infrastruktúrával (szerverek, OPFOR és DISTAFF munkahelyek, hálózati). A telepítési helyszínen az alájátszói munkahelyeket a szolgáltatást igénybe vevő fél szolgáltatja, azok csatlakoznak a mobil rendszerre. A kiképző csoport végrehajtja az alájátszók és a gyakorlók kiképzését is.

A fejlesztések új lehetőségeit a NATO együttmüködésbe való erőteljesebb bekapcsolódás jelentheti. A NATO vezetöi 2020-ban elfogadták a „NATO 2030” szakértői jelentést, amelynek célja, hogy 2030-ra létrejöjjenek olyan koherensen bevethetö, interoperábilis és fenntartható erők, amelyek felszerelése, kiképzése, gyakoroltatása és vezetése megfelel a NATO ambícióinak és képesek együttmüködni bármilyen környezetben. ${ }^{51}$ A NATO már 15 éve az Összhaderőnemi Kiképző Központban (JFTC) ${ }^{52}$ a lengyelországi Bydgoszcz-ban, évi egy alkalommal megrendezi a CWIX $^{53}$ gyakorlatot, amelyben a NATO nemzetek által használt különböző vezetési, szimulációs és egyéb informatikai rendszerek, képességek interoperabilitását tesztelik. ${ }^{54} \mathrm{~A}$ munka célja, hogy a NATO rendszerek együttmüködését hatékonyan lehessen fejleszteni. A fejlesztés során tudósok vizsgálják a kialakulóban lévő interoperabilitási szabványokat és megoldásokat, mérnökök végzik az új megoldások kipróbálását, tesztelők vizsgálják a kihelyezett és a tervezett bevethető képességek közötti müszaki átjárhatóságot, valamint a felhasználók használják és ellenőrzik az interoperabilitási képességeket egy releváns forgatókönyv alapján. A tesztek alcsoportokban (focus areas)

\footnotetext{
${ }^{50}$ JTLS - Joint Theater Level Simulation, Rolands \& Associates Corp. / Hadszintéri szintü összhaderőnemi szimuláció.

${ }^{51}$ Szenes 2021, 15.

52 Joint Force Training Center alapvetően szárazföldi kiképző központ, ahol dandár szintig műveleti kitelepítés előtti kiképzések folynak.

${ }^{53}$ CWIX - Coalition Warrior Interoperability eXercise - Koalíciós harci interoperabilitási gyakorlat.

${ }^{54} \mathrm{https} / / / \mathrm{www}$. act.nato.int/federated-interoperability
} 
zajlanak, amelyekhez lehet csatlakozni. Az előkészítés során derül ki, hogy ki, mit szeretne tesztelni és ahhoz partnert is kell találni. Magyarország jelenleg 4 alcsoportban dolgozik: $\mathrm{FMN}^{55}$ (általános hálózati, infrastrukturális tesztek), kibervédelem, modellezés és szimuláció (ARTIFEX), valamint a szárazföldi erök (HM EI, C2).

A szimulációs munkacsoportba a Magyar Honvédség (MH) a MARCUS képességet ajánlotta fel. A fejlesztők számos interoperabilitási tesztet hajtottak végre mind szimulációk, mind $\mathrm{C} 2 / \mathrm{C} 4$ vezetési rendszerek irányába. Ez a terület folyamatos karbantartást igényel, mivel a különböző informatikai rendszerek folyamatosan változnak, fejlődnek, így ezek kommunikációját is folyamatos igazítani kell.

A munkacsoportokba delegálni kell résztvevőket és gondoskodni kell a tevékenység finanszírozásáról, különben az MH kimarad ebből a NATO együttmüködésből. Célszerü lenne, ha az MH részt venne a NATO CAX fórumon is, amely évente kerül megrendezésre mint a legmagasabb szintü NATO rendezvény szimulációs kiképzés témakörben. A rendezvényt a NATO Modellezési és Szimulációs Kiválósági Központja (Modelling \& Simulation Centre of Excellence (Róma) koordinálja. Időtartama 3+1 nap, 30-40 ország, 250300 résztvevő, számos magán cég és állami szervezet kapcsolódik be. Az előadások alapján a magyar képességek nemzetközileg is ismertek, rendszeresen említésre kerülnek az előadásokban.

\section{Következtetések}

A katonai szimulációk területén Magyarországon nemzetközi összehasonlításban is kiváló termékek találhatóak. A Magyar Honvédség várpalotai Szimulációs Központjában és még számos helyőrségben, a nemzetközileg is elismert színvonalú MARCUS konstruktív szimulációs rendszer üzemel, amely biztosítja a törzskiképzés teljes körü kiszolgálását. A MARCUS rendszer nem csak katonai, hanem polgári célú felhasználásra is alkalmas. A rendszer bővíthető a katasztrófavédelem, kritikus infrastruktúra védelem, terrorizmus és kábítószer kereskedelem elleni harc kiképzési faladataival. A konkurens rendszerekkel ellentétben a MARCUS szimuláció rendkívül rugalmasan, az egyedi igényekre gyorsan alakítható, $\mathrm{s}$ akár a felhasználó által is könnyen bővíthető.

Az elmúlt évben elindult a MARCUS szoftver következő generációjának fejlesztése. A felhasználói igények alapján történő fejlesztés végrehajtása után a MARCUS szimuláció nem csak új képességekkel, hanem költséghatékonyabb müködtetés lehetőségével is rendelkezik majd. Az egyik fontos elem az, hogy a rendszer jól tervezhető költség és humánerőforrás szintek mellett, kevesebb, a feladatot csak eseti jelleggel végrehajtó, kezelői létszámmal (akár az alkalmazó saját üzemeltetésével) is hatékonyan müködtethetö legyen.

Az elmúlt évtizedek tapasztalatai alapján azonban célszerủ a meglévő üzemeltetési rendet felülvizsgálni. Az új üzemelési renddel a Magyar Honvédség a NATO-ban manapság szokásos eljárásokat tudná alkalmazni a CAX gyakorlatok lefolytatása során.

Ehhez, és a Zrínyi HHP programhoz kapcsolódó további szimulációs rendszerek beszerzése, beüzemelése, integrációja miatt, szükséges lehet az alkalmazói követelmények

\footnotetext{
${ }^{55}$ FMN - Federated Mission Network / Szövetséges Müveleti Hálózat.
} 
MARCUS-ra vonatkozó meghatározása és a szükséges fejlesztések elindítása. Ennek eredményeképpen a Magyar Honvédség továbbra is egy fejlett CAX rendszer segítségével folytathatja a kiképzési feladatait.

A közös fejlesztés pedig egy igazi sikertörténetté válhat, hiszen egyike a magyar védelmi ipar versenyképes termékeinek. A hazai rendszer további korszerüsítése egyben lehetőséget biztosít a magyar egyetemek bekapcsolódására, nemzetközi együttműködésekre, így a kormányzati céloknak megfelelően hozzájárulhat a magyar védelmi ipari termékek exportjához.

\section{FELHASZNÁLT IRODALOM}

A NATO 2020 koncepció ismertetője:

https://www.nato.int/cps/en/natolive/official_texts_63654.htm (Letöltve: 2021. 02. 19.)

A NATO interoperabilitással kapcsolatos kezdeményezései:

https://www.act.nato.int/federated-interoperability (Letöltve: 2021. 08. 22.)

Brawe Warrior 2016 számítógéppel támogatott törzsvezetési gyakorlat.

https://caxsupport.wordpress.com/2016/10/04/brave-warrior-2016/ (Letöltve: 2021. 02. 19.)

Budavári Krisztina 2019. A Zrínyi 2026 program. Korlátozott lehetőségek a magyar védelmi ipar fejlesztésére.

http://real.mtak.hu/105874/1/2019eA\%20Zr\%C3\%ADnyi\%202026\%20program_Budavá ri\%20Krisztina.pdf (Letöltve: 2021. 02. 19.)

Erdal Cayirci, Dusan Marincic: Computer Assisted Exercises and Training: A Reference

Guide, Wiley \& Sons, 2009, ISBN: 978-0-470-49861-3 http://www.artifex.hu/hu

(Letöltve: 2021. 02. 19.)

European Defence Agency: CBRN SaaS project enters operational phase.

https://eda.europa.eu/info-hub/press-centre/latest-news/2021/01/21/cbrn-saas-project-

enters-operational-phase (Letöltve: 2021. 02. 19.)

EXODUS szimuláció alkalmazási példák:

https://fseg.gre.ac.uk/fire/EXODUS_animations.asp (Letöltve: 2021. 02. 19.)

GAMMA Müszaki Zrt. honlapja: http://www.gammatech.hu (Letöltve: 2021. 02. 19.)

Judson, Jen 2019. US Army's jumping to the next level in virtual training. https://www.defensenews.com/land/2019/05/17/us-armys-jumping-to-next-level-invirtual-training-world/ (Letöltve: 2021. 02. 19.)

Kapás Viktor István hadnagy 2018. Szimulációs térben küzdöttek. https://honvedelem.hu/hirek/hazai-hirek/szimulacios-terben-kuzdottek.html (Letöltve: 2021. 02. 19.)

Kállai Attila 2016. Felkészítés és kiképzés virtuális környezetben. Humánvédelem békeműveleti és vészhelyzet-kezelési eljárások fejlesztése (Tanulmánygyüjtemény I. ebook), 4 . 
http://real.mtak.hu/33554/1/tanulmanygyujtemeny\%20_ujratervezes_CsJ_KZ_1.5.pdf (Letöltve: 2021. 02. 19.)

Kálmánfi, Gábor 2015. Joint Simulation. https://honvedelem.hu/hirek/joint-simulation.html (Letöltve: 2021. 02. 19.)

MG Gervais d.n. MG Maria R. Gervais: Synthetic Training Environment Cross Functional Team Army Futures Command: Revolutionizing Training Through the Synthetic Training Environment; https://www.idga.org/events-synthetictraining/downloads/majorgeneral-maria-r-gervais-on-the-synthetic-training-environment-cross-functional-team (Letöltve: 2021. 02. 19.)

Military Training and Simulation. The Concise Global Industry Guide, October 2021. Shephard Handbook Issue 17. https://www.shephardmedia.com/news/trainingsimulation/read-the-latest-military-training-and-simulation-h/ (Letöltve: 2021. 12. 11.)

Molnár Anna, Szabolcs Laura 2020. Megerősített, változó geometria, PESCO. Hadtudomány 30 (4): 95-97.

NATO CA2X2_2020 Forum: Presentation_43_Cross-Functional-Team-Synthetic-TrainingEnvironment.pdf (Letöltve: 2021. 02. 19.)

PESCO Projects: Chemical, Biological, Radiological and Nuclear (CBRN) Surveillance as a Service (CBRN SaaS). https://pesco.europa.eu/project/chemical-biological-radiologicaland-nuclear-cbrn-surveillance-as-a-service-cbrn-saas/ (Letöltve: 2021. 02. 19.)

PESCO Projects: INTEGRATED EUROPEAN JOINT TRAINING AND SIMULATION CENTRE (EUROSIM). https://pesco.europa.eu/project/integrated-european-jointtraining-and-simulation-centre-eurosim/ (Letöltve: 2021. 02. 19.)

Rhodes 2021. Carey Rhodes: US Army's Synthetic Training Environment (STE). https://www.apexofficer.com/synthetic-training-environment (Letöltve: 2021. 02. 19.)

Swan d.n. Pete Swan: The Trend Toward Common Architectures. https://www.itec.co.uk/_media/libraries/draft-abstracts--slides/40---Peter-Swan--slides.pdf (Letöltve: 2021. 02. 19.)

Tamás Attila 2015. Kiképzés-felkészítés virtuális (szimulációs) környezetben. In Krajnc Zoltán, Csengeri János (szerk.): A hadtudomány és a hadviselés komplexitása a XXI. században. 175. http://real.mtak.hu/31932/7/konyv_vegleges_mta_real.pdf_(Letöltve: 2021. 02. 19.)

Szenes Zoltán 2021. Merre tovább, NATO? A Szövetség új stratégiai koncepciót készít. Honvédségi Szemle 149 (6): 15-16.

Szilágyi Imre százados 2018. Gyakorlat a borostyánút mentén. https://honvedelem.hu/hirek/hazai-hirek/gyakorlat-a-borostyanut-menten.html (Letöltve: 2021. 02 .19.)

Szilágyi Imre százados 2019. CWIX: Együttmüködési gyakorlat Lengyelországban. https://honvedelem.hu/hirek/hazai-hirek/cwix-egyuttmukodesi-gyakorlatlengyelorszagban.html (Letöltve: 2021. 02. 19.) 
Tasi Tibor 2020. Korszerü eszközökkel oktatják az elektronikai hadviselést. https://www.uninke.hu/hirek/2020/01/27/korszeru-eszkozokkel-oktatjak-az-elektronikai-hadviselest (Letöltve: 2021. 02. 19.)

Varga Bernadett zászlós 2015. Központban a szimulációs hálózati rendszer. https://honvedelem.hu/hirek/hazai-hirek/kozeppontban-a-szimulacios-halozatirendszer.html (Letöltve: 2021. 02. 19.) 